\title{
不圧地下水の井戸壁における不連続水位の評価について
}

\section{On the Evaluation of the Discontinuous Water Level Arising at the Well-Wall by Pumping in an Unconfined Aquifer.}

\author{
星田義治*・市川 勉*・前原弘光** \\ Yoshiharu HOSHIDA, Tsutomu I I IKawa \\ and Hiromitsu MAEHARP
}

\begin{abstract}
When unconfined ground water is pumped through a well, discontinuous water level arise at the well-wall.

It has been cleard by theory and tests the phenomenon is caused by the resistance of casing and vertical flow near the well-wall in the aquifer. The results are expressed as follows :

1) When the opening area ratio of the casing is smaller than $10 \%$, the discontinuous water level is mainly caused by the resistance of casing.

2) When the opening area ratio of the casing became larger and the ratio of pumping water level to static water level is smaller then 0.6 , it is mainly caused by vertical flow near the well-wall in the aquifer.
\end{abstract}

Using this method, the properties of aquifer can be estimated more accurately through field test.

\section{1. 緒 論}

不圧地下水を井戸から揚水すると，井戸壁内外において水位の不連続が生じる。この現象の原因の 一つに，揚水される水が井戸枠の収水孔を通過する際に発生する井戸枠の抗抵による井戸損失が考え られる。この井戸損失については，狩野(1)の実験的研究および井戸枠の抵抗を Darcy 型で表現した 鴄(2)の研究がある。著者らは井戸の近傍で乱流が発生することを考え，乱流領域の抵抗をも表現でき る抵抗係数を用いた運動方程式を提案した。

しかし, 不王地下水の場合, 井戸枠の抗抵による井戸損失がない場合でも水理的必然として, 鉛直 流による不連続水位が生じる。この下連続水位の研究に野満(3)の報告がある。野満はこの解を導く過 程で鉛直流成分が帯水層基底面からの距離に比例するという仮定を用いている。著者らは有限要素法 による定常三次元解を行って，この不連続水位差を定量化した， 
本報告に招いては，この不連続水位に占める鉛直流の影響，及び近似的に井戸椊の抗抵による井戸 損失とみなした場合の乱流型運動方程式の抵抗係数について検討を加え，この抗抵俰数を用いて非定 常解析を試みた。

\section{2. 井戸枠の抵抗を考虑した非定常解析}

（1）井戸枠の抵抗を考慮した井戸にお打る運動式

図一 1 に示すように，井戸内の水位を $h_{w}$ ，井戸枠外の水位を $h_{s}$ とし， $h_{w}$ 区間から井戸への浸み 出し量を $Q_{1}, \quad\left(h_{s}-h_{w}\right)$ 区間からの浸み出し 量を $Q_{2}$ とする。井戸枠の収水孔が連続的に 一様に分布し, 井戸枠の両側の流速は近似的 に等しいと仮定する。地下水が井戸枠を通過 する際の抵抗係数を $K$ と扔くと井戸枠からの 乱流型の浸み出し量は次のようになる。

$$
\begin{aligned}
& Q_{1}=2 \pi r_{0} \int_{0}^{h_{w}} K \sqrt{\left(h_{s}-y\right)-\left(h_{w}-y\right)} d y \\
& Q_{2}=2 \pi r_{0} \int_{h_{w}}^{h_{s}} K \sqrt{h_{s}-y} d y \\
& Q_{s}=Q_{1}+Q_{2}=2 \pi r_{0} K\left(h_{s}-h_{w}\right)^{\frac{1}{2}} \frac{2 h_{s}+h_{w}}{3}
\end{aligned}
$$

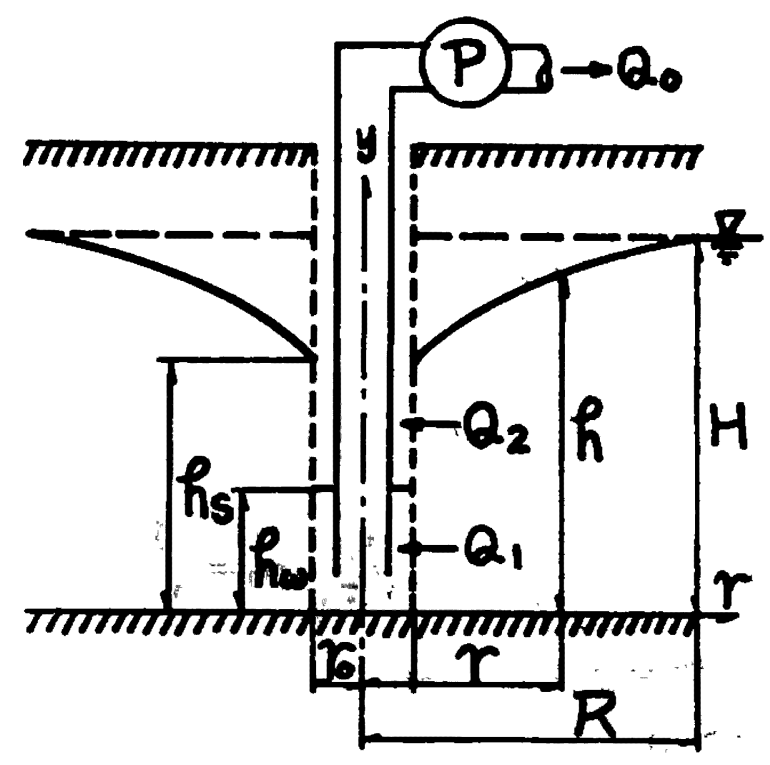

困一1 不仕帯水層モデル（二次元）

ここに,

$$
K=\sqrt{\frac{2 G}{\Sigma f}}
$$

$\mathrm{G}:$ 重力加速度, $\Sigma f:$ 損失係数

また，井戸内の連続式は次のようになる。

$$
\left(A_{w}-A_{p}\right) \frac{\mathrm{d} h_{w}}{\mathrm{~d} t}=Q_{s}-Q_{0}
$$

ここに, $A_{w}, A_{p}$ : 井戸の断面積, 揚水管の断面積

（2）帯水層内の基礎式

帯水增は均質等方であり， Darcy の法則および準一様流の仮定を用いると帯水層内の非定常流れ の基礎式は次のように表わせる。

$$
\frac{\partial h}{\hat{o} t}=\frac{k}{\beta} \frac{1}{r} \frac{\partial}{\partial r}\left(r h \frac{\hat{c} h}{\partial r}\right)
$$

ここに, $k$ : 透水係数, $\beta$ : 有効空隙率

(3) 数值解析

次のよらな無次元量を用いて無次元化すると， 


$$
\left.\begin{array}{l}
g=\frac{h}{H}, g_{w}=\frac{h_{w}}{H}, g_{s}=\frac{h_{t}}{H}, x=\frac{r}{r_{0}}, \tau=\frac{k H t}{\beta r_{0}^{2}} \\
\alpha=\frac{r_{0} K}{k H^{1 / 2}}, Z_{s}=\frac{Q_{s}}{2 \pi k H^{2}}, Z_{0}=\frac{Q_{o}}{2 \pi k H^{2}}, \beta^{\prime}=\frac{\beta}{1-\frac{A_{p}}{A_{w}}}
\end{array}\right\}
$$

式 (2-1)，(2-3)，(2-4) は次のよ5になる。

$$
\begin{aligned}
& Z_{s}=\alpha\left(g_{s}-g_{w}\right)^{1 / 2} \frac{2 g_{s}+g_{w}}{3} \\
& \frac{d g_{w}}{d \tau}=2 \beta^{\prime}\left(Z_{s}-Z_{0}\right) \\
& \frac{\partial g}{\partial \tau}=\frac{1}{x} \frac{\partial}{\partial x}\left(x g \frac{\partial g}{\partial x}\right)
\end{aligned}
$$

式（2-8）は数值計算しやすい上らに変数变換すると次のような連立常微分方程式となる(4)。

$$
\left.\begin{array}{l}
\frac{d g}{d \xi}=\frac{Z}{\xi g} \\
\frac{d Z}{d \xi}=-\frac{y_{0}^{2} \xi Z}{2 g}
\end{array}\right\}
$$

ここK, $\xi=\frac{y}{y_{0}}, \quad y=\frac{x}{\sqrt{\tau}}, y_{0}=\frac{1}{\sqrt{\tau}}, \quad Z=\frac{Q r}{2 \pi k} \bar{k} H^{2}$

初期条件および式 (2-6)，（2-7）を考虑した境界条件は次のようになる。

$$
\begin{aligned}
& \tau \geq 0 \quad g=g_{s}=g_{w}=1, Z=0 \\
& \tau<0 \quad Z_{0}=\text { 一定汲及出し量 } \\
& x=1, \frac{d g_{w}}{d \tau}=2 \beta\left(Z_{\imath}-Z_{0}\right) \\
& Z_{s}=\alpha\left(g_{i}-g_{w}\right) \frac{1 / 2}{2 g_{s}+g_{m}} \\
& x=X\left(=R / r_{0}\right), \quad g=1
\end{aligned}
$$

数値計算は式（2-9，が式（2-10）を満足するよらに，Runge-Kutta 法で行った。

\section{3. 有限要素法による定常三次元放射流解析}

図一2において，均筫等方な帯水層内の定常三次元放射流の支配方程式は次のように表わせる。

$$
\frac{\partial}{\partial r}\left(r \frac{\partial h}{\partial r}\right)+\frac{\partial}{\partial r}\left(r \frac{\partial h}{\partial z}\right)=0
$$

但し, $h=P / w+Z$

ここに, $P$ : 水圧, $w:$ 水の単位体積重量

境界条件は次の上うに定める。

二点境界值問題として扱らと境界 $\mathrm{A}_{1}, A_{3}$ は静水圧となる。 


$$
h=h_{w} \quad \text { on } A_{1}, h=H \quad \text { on } A_{3}
$$

境界 $A_{\mathbf{2}}$ は浸出面積を表わす。

$$
h=Z(P=0)
$$

境界 $A_{4}$ は不透水層であり, 境界 $F S$ は自由 水面を示す。

$$
\frac{\partial h}{\partial z}=0 \quad \text { on } A_{4}, \quad \frac{\partial h}{\partial n}=0
$$

$$
\text { and } p=0 \text { onFS }
$$

上記の境界条件で式 (3-1)を有限要素法で 解く。有限要素法を用いて浸出面の位置を求 める場合, この位固は揚水井近傍の要素分割 灶大き影響する。従って，要素分割につい ては十分安定性を検討し，図一3のようなモ デルで解析した。

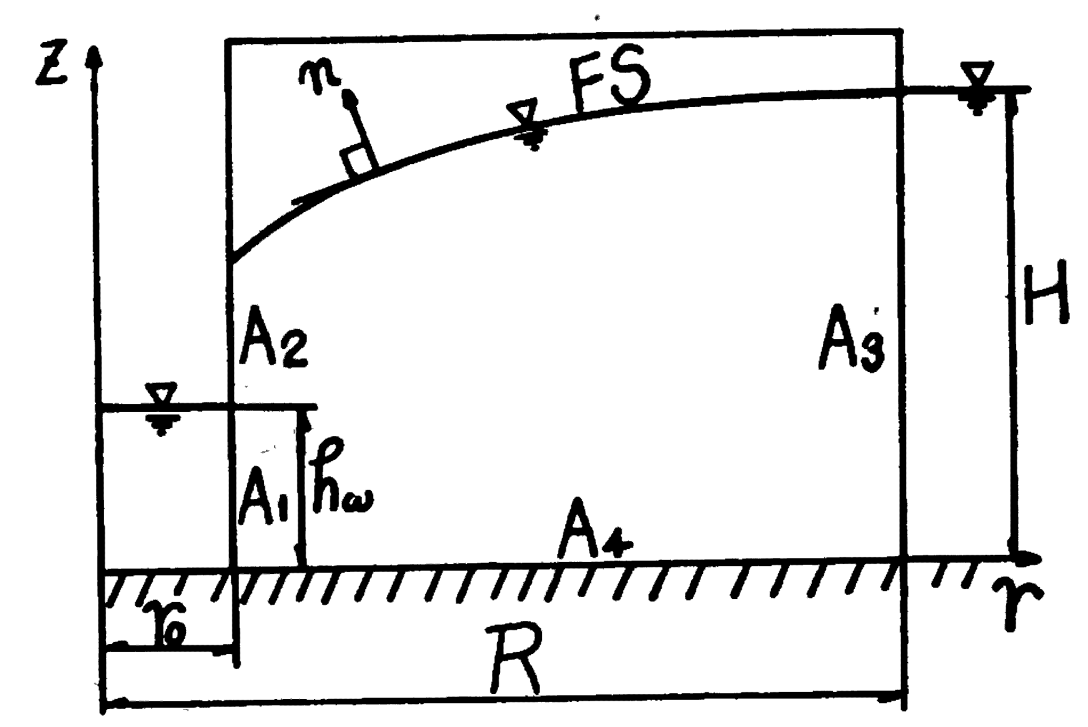

図一2＼cjkstart不圷帯水層モデル（三次元）

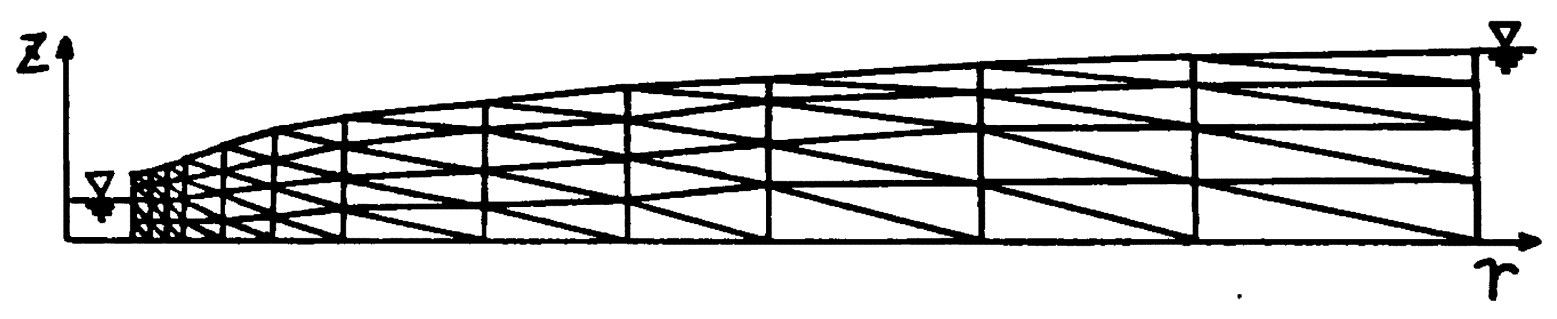

図-3 要素分割

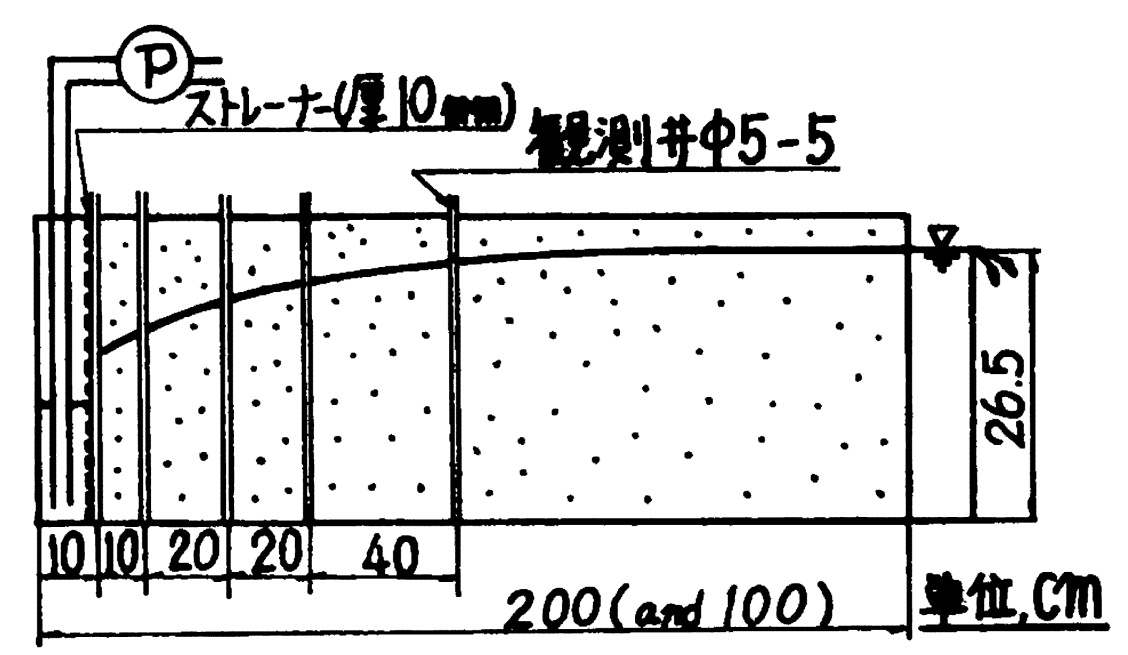

圀一４実験装置模式困

\section{4. 模型実験}

実験装置は，円型の $1 / 24$ の扇型水槽を用いた。四一 4 は模式断面目を示す。井戸壁外の水位はスト レーナに接して $\phi 5 \mathrm{~mm}$ の観測井を設け，他の観測井同様に井底から逆サィフォンでマノナータに導き 測定する。揚水井のストレーナとして，開孔率の異なる 5 ケースの井戸枠を用いる。開孔率は帯水首 


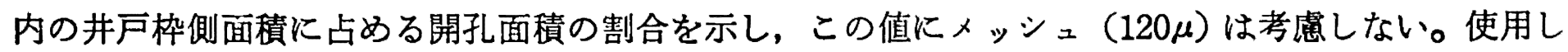
た充填試料は有効粒径 $0.43 \mathrm{~mm}$, 均等係数 1.49 の寒川産砂, 及び豊浦標準砂である。涵養半径は $2.0 \mathrm{~m}$ および 1.0 mを採用する。各ヶースにつき揚水量を変えて非定常ならびに定常実験を行った。

\section{5.＼cjkstart鉛直流の影響による不連続水位}

一般に，動水勾配が大きくなると Dupuit-Forchheimer の準一様流い仮定は成り立たず，鉛直流 成分は無視できなくなる。準一様流の仮定を用いた Thiem の解と鉛直流を考慮した野満の一次解 及び F. E. M の数值解に実験データを適用すると四一 5 のようになる。動水勾配の大きい揚水井近

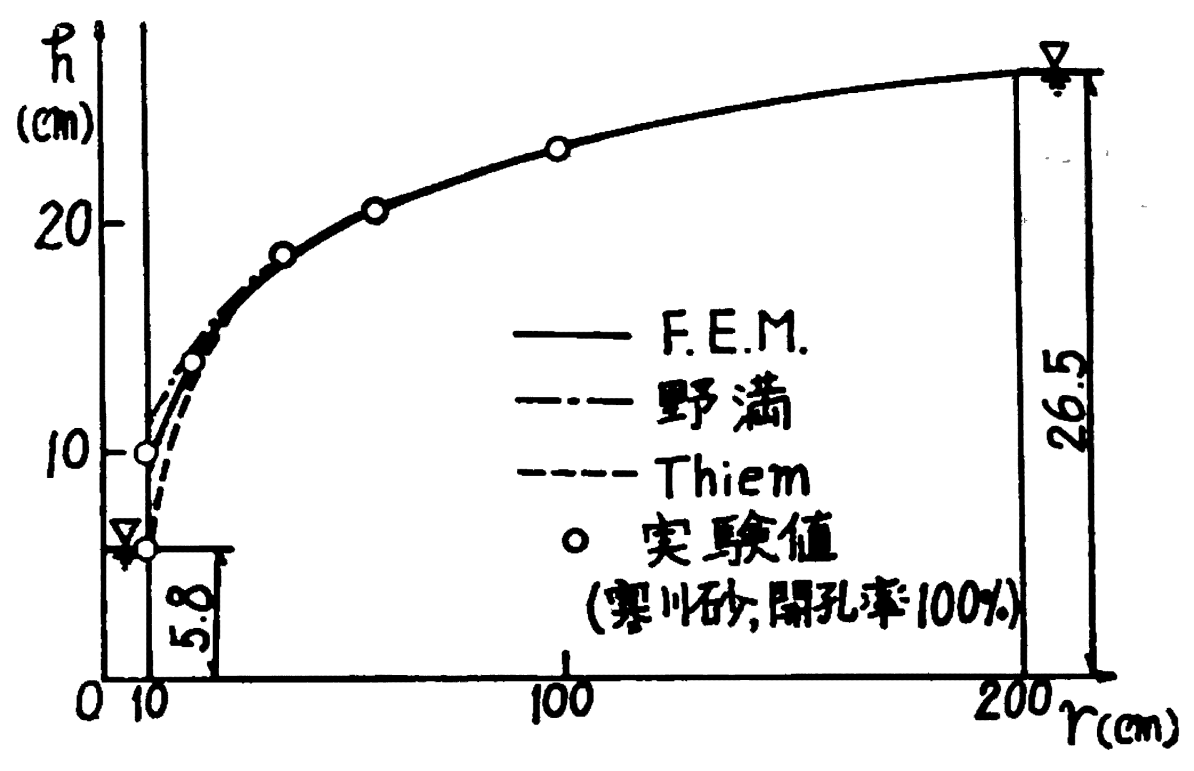

困一 5 二次元解之三次元解の比較

傍に括いてのみ鉛直流の影響を示して扣り，動水勾配の小さい位置では三つの解とも一致している。 因のような適用を数ケース行い，銘直流によって生じる不連続水位差と井戸内の水位の関係を示すと

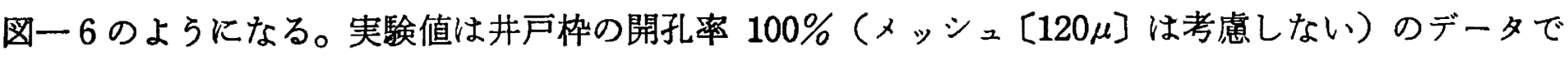

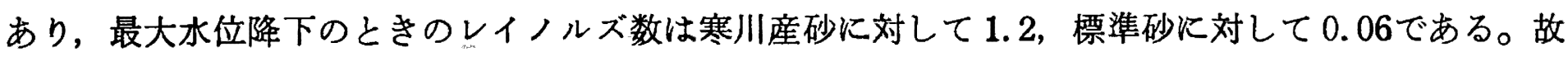
に帯水層内では層流とみなせる。ここに, レイレルズ数 $\left(R e=V D_{10} / \nu . \nu\right.$ ：動粘性係数 $D_{10}: 10 \%$ 粒 径, $\mathrm{V}$ : 流速) 計算に用いた流速は揚水量 $\left(Q_{0}\right)$ を井戸枠外水位の流出面積 $\left(2 \pi r_{0} h_{s}\right)$ で割ったもの である。野満の解とFE Nの数值解に差異が認められるが，野満の解は一次解であり十分議論できな い。FEMの数值解においては比水位 $\left(h_{w} / \mathrm{H}\right) 0.5$ 付近より鉛直流による不連続水位差が急增するが 実験值もほぼ同様な傾向が認められる。実験值と理論值が一致しない理由として, 井戸枠外の水位を 井戸枠に接して観測井を設け測定されているために実際より大さく評価されていること，及び開孔率 $100 \%$ 井戸枠においても若干の抗抵があることが考えられる。

以上から, 井戸内の水位降下が大きい場合, 井戸壁に拈ける不連続水位差に占める鉛直流の影響が. 大きいことがうかがえる。

\section{6. 井戸枠の抵抗係数}

実験より測定される井戸内の水位 $\left(h_{w}\right)$ と井戸枠外の水位 $\left(h_{s}\right)$ の差が近似的に井戸枠の抗抵によ 


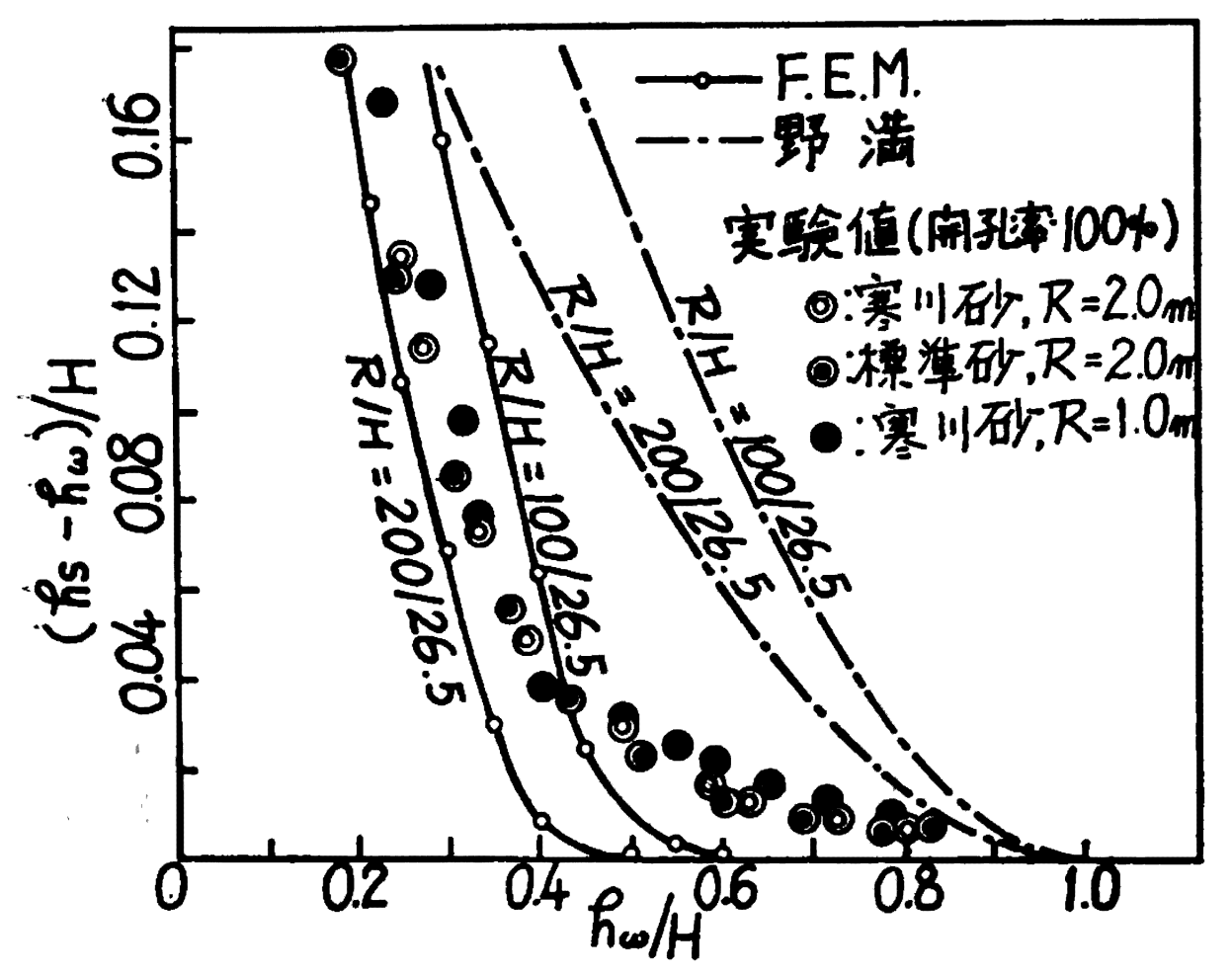

図一 6 井戸壁における不連続水位差と井戸内の水位

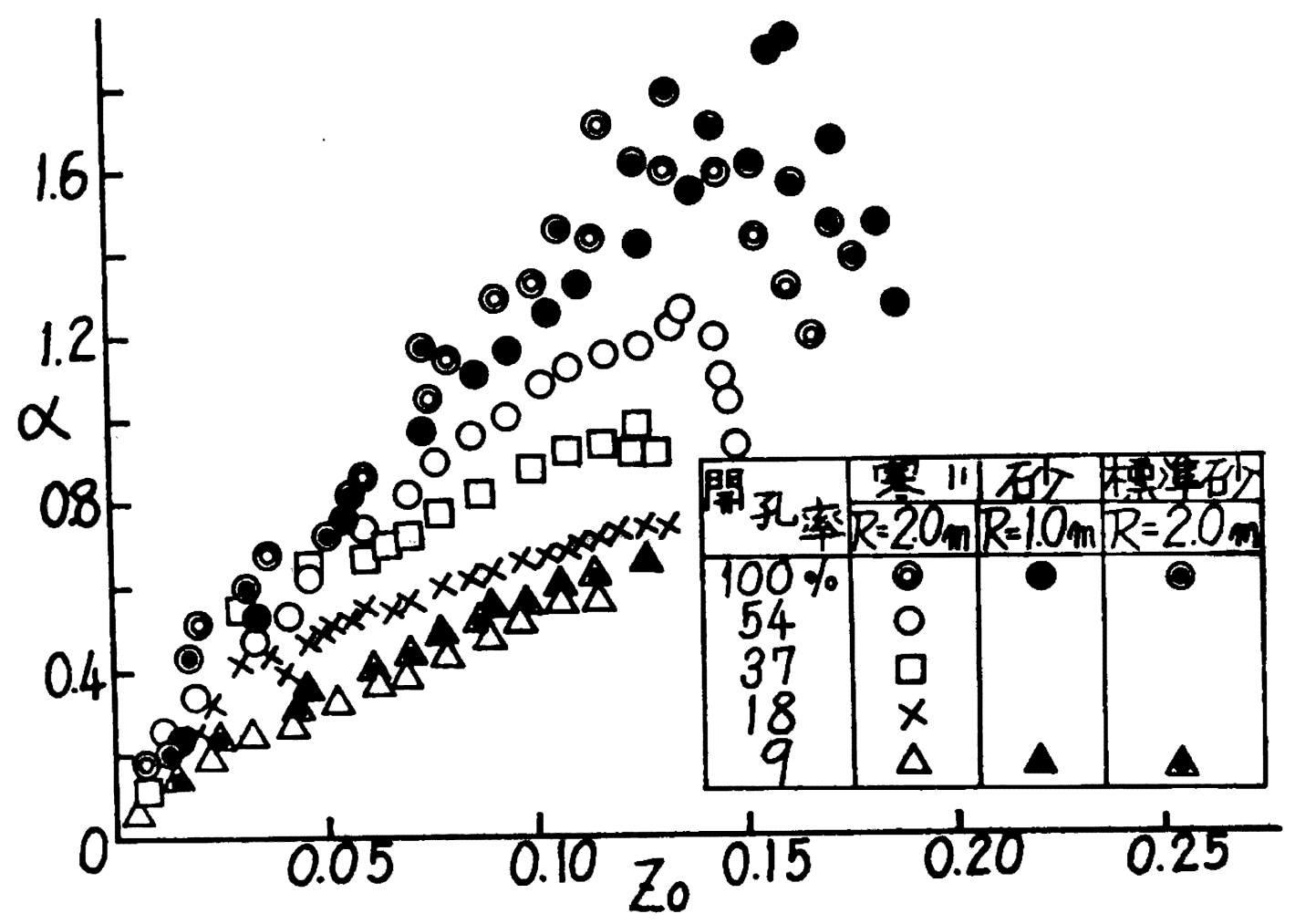

因一7 無次元抵抗係数 $(\alpha)$ と無次元汲及出し $\left(\mathbf{Z}_{0}\right)$ の関保

って生したものとみなし，実験から測定される定常状態の $Z_{0}\left(\approx Z_{s}\right), g_{w} ， g$ ，を用いて式 $(2-6)$ よ り無次元抵抗係数 $(\alpha)$ を算定すると, 無次元抵抗係数 $(\alpha)$ 無次元汲み出し量 $\left(Z_{0}\right)$ の関釈は図一 7 のようになる。ここに， $Z_{0}$ の計算に用いた透水係数 $(k)$ は Thiem の定常解より求めたすのであ る。井戸枠の開孔率が大きい場合， $Z_{0}$ が大きくなると $Z_{0}$ との比例関係はくずれているが，この位 置を比水位 $\left(h_{w} / H\right)$ で示すと0.45位である。この位㯰は図一6において，鉛值流の効果が急增する 
位置とほぼ一致していることから，鉛直流の影響によるものと考える。すなわち，鉛直流によって生 じる浸出面をも含めて井戸枠の抵抗による井戸損失とみなして式(2-6) よりを算定したために比例関， 係がくずれたものと思われる。Z゙が小さい場合または開孔率が小さい場合は比例関係が保たれて括り 不連続水位差に占める鉛直流の影響が少なく，井戸枠の抵抗が卓越している。また充填試料及び涵養 半径に関係なく $\alpha$ は井戸枠の開孔率をパラメーターとして同じ傾向を示す。

以上の考察から，鉛直流の影響の卓越しない開孔率の小さい場合に怙いて，また開孔率の大きい場 合は汲み出し量が小さい範囲 $\left(Z_{0}\langle 0.1)\right.$ 飞执いて， $\alpha$ の概略值を推定することがでさると考える。

\section{7. 井戸伜の抵抗を考虑した非定常解の適合性}

井戸枠の抵抗を考慮した非定常解析をする場合, 式 (2-6) の無次元抵抗係数 $(\alpha)$ は入力データと して与えなければならない。この $\alpha$ は実験的に定める必要があり, 図一 7 の定常実験算定值を非定常 解析の $\alpha$ として第 1 近似的に採用する。

数值計算は井戸枠の無次元抵抗係数 $(\alpha)$ ，有効空隙率 $(\beta)$ ，無次元汲み出し量 $\left(Z_{0}\right)$ を最初に 与え, 無次元時間 $\left(\mathrm{y}_{0}\right)$ をパラメーターとして計算する。

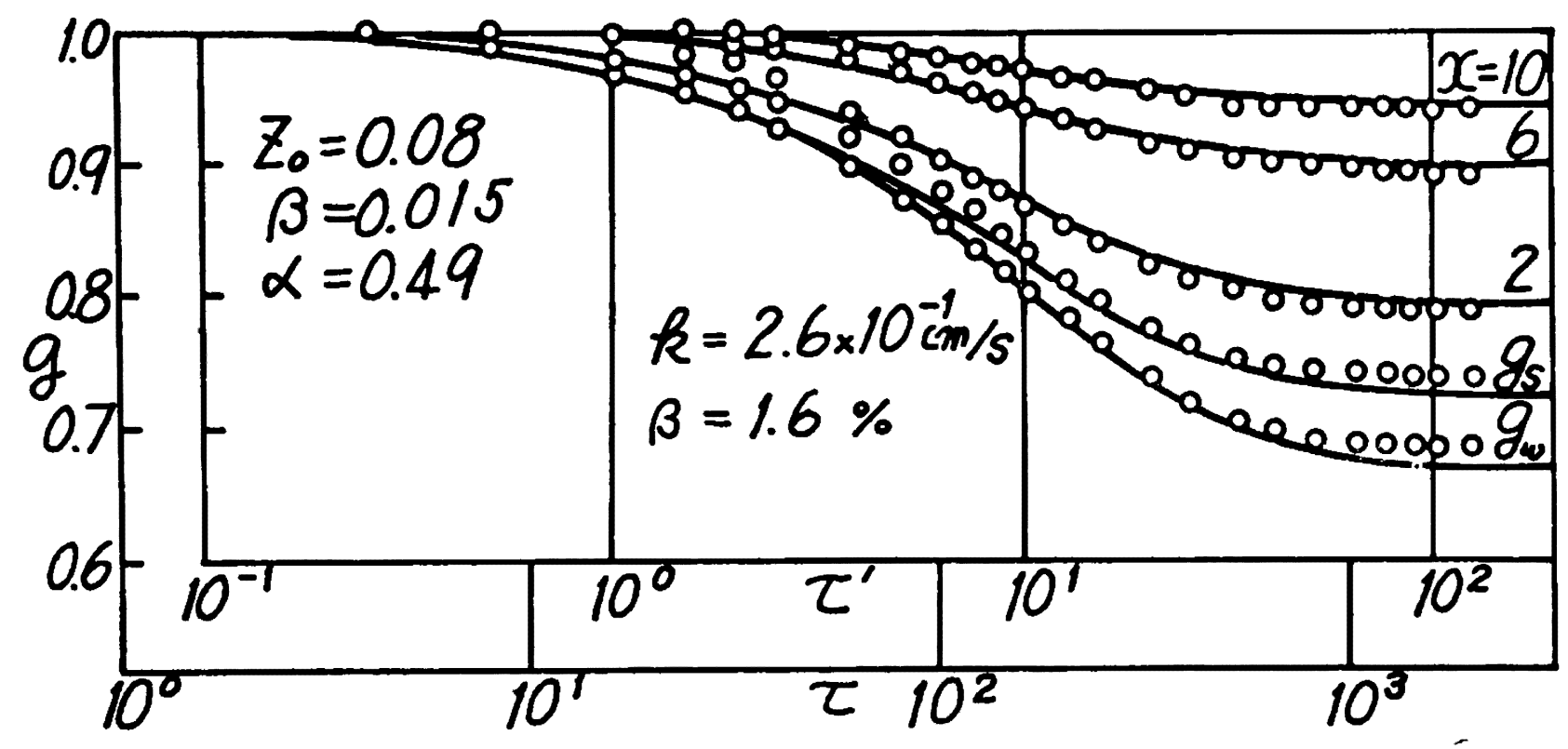

図一8 井戸枠の抵抗を考感した非定常解の適合性

図一8 は数值解に実験値を適用したものである。ここに，実験データの横軸では $\mathrm{Ht} / \mathrm{r}_{0}{ }^{2}$ である。 また図中央の透水係数 $k\left(=\frac{Q_{0}}{2 \pi Z_{0} H^{2}}\right)$ 及び有効空隙率 $\left.\beta\left(K \times \tau^{\prime} / \tau\right)\right)$ はこの適用因から求められる. 值である。井戸損失量 $\left(\mathrm{g}_{\mathrm{s}}-\mathrm{g}_{\mathrm{w}}\right)$ を含めて時間的及び空間的な水位変動がほぼ評価されている。

図一9は水位降下量が大きい場合の適用図である。動水勾配の大きくなる揚水井戸近傍で水位変動 が評価できてないが，これは井戸枠の抵抗式（2-6）によるるのではなく，基礎式（2-4）に準一様流 の仮定が用いられているためと考えられる。この図に拈いても井戸損失量はだいたい正しく評価され ている。

著者らが行った適用例では，帯水層内の最大水位降下率40\%をで図一8のように揚水井近傍も評価. できていた。この値は図一6において，FEMによる定常三次元解析の準一様流の適用限界，すなわ 


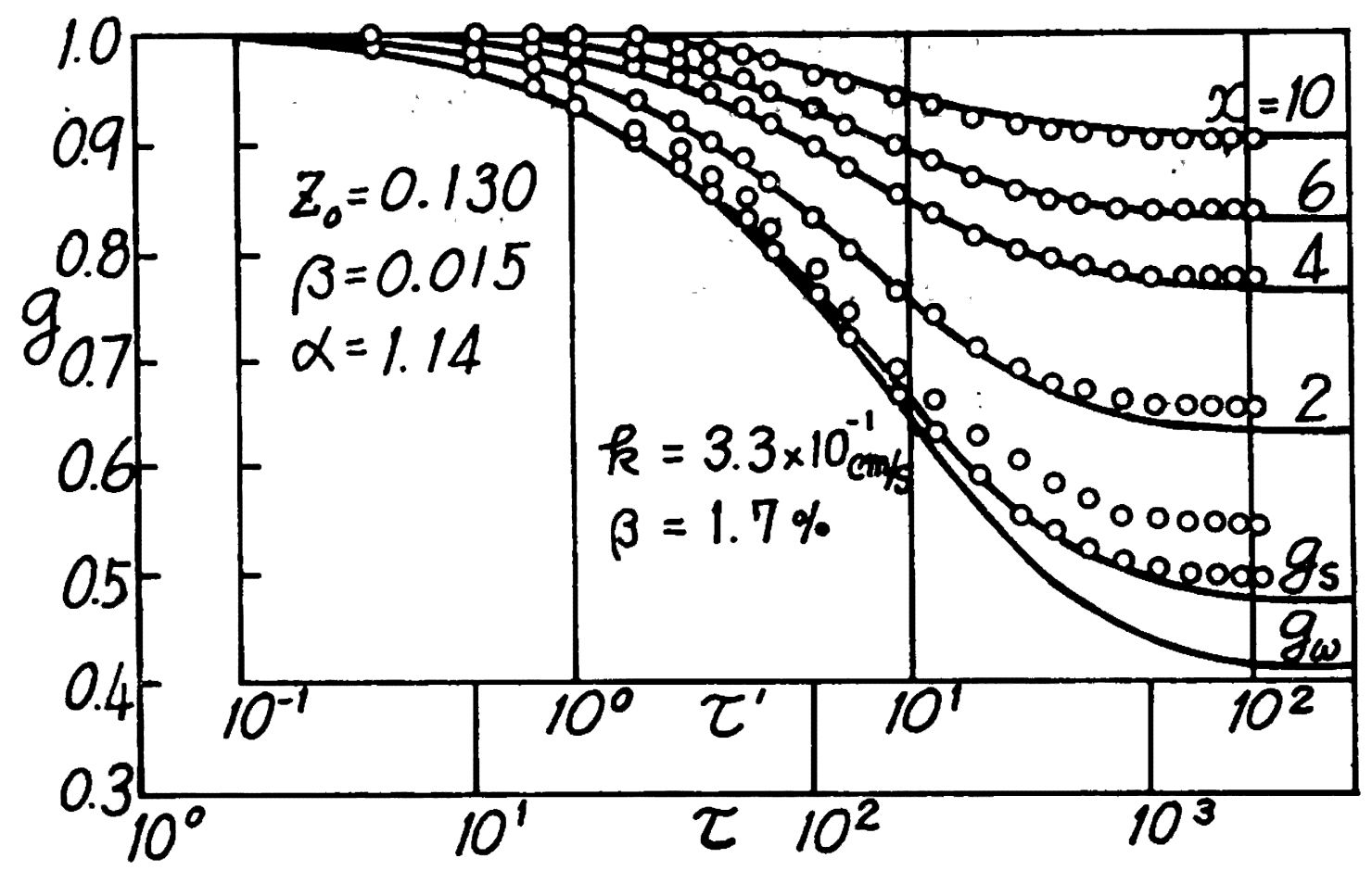

図一－井戸枠の抵抗を考虑した非定常解 6 適合性

ち水位降下率50\%とほぼ一致している。従って，水位降下量が大きい場合，揚水井近傍で水位変動が 評価でさないのは準一様流の仮定によるものと思われる。故に, 非定常三次元解析を行って, 今後、 検討する必要があろう。

\section{8. 結 論}

\section{以上の考察をまとめると次のことが言える。}

1）揚水井半径に比較し涵養半径の大さな放射流に打いて，井戸内の水位降下率50\%付近から井戸壁 に打ける不連続水位に占める鉛直流成分が急増する。また,このことは準一様流の適用限界を示す。 2）井戸枠の抵抗を考慮した乱流型の運動方程式 $(2-6)$ の無次元抵抗係数 $(\alpha)$ は鉊直流の卓越しな い範囲において，井戸枠の開孔率をパラメーターとして無次元汲み出し量 $\left(Z_{0}\right)$ に比例する。また $Z_{0}$ と $\alpha$ の困より鉛直流の影響の有無を見ることがでさる。

3）定常実験より算定した無次元抵抗係数（ $\alpha$ ）非定常解析に用いても，非定常過程の井戸損失量を ほぼ評価できる。故に図一 7 よ $\alpha$ の概略值を推定して, 現地試験における井戸損失を考虑した非 定常解析がでさることになる。

\section{参考 文 献}

（1）狩野徳太郎：『井戸壁内外の水位差』，農業土木研究No. 3，1934

(2) 嶋祐之：井『戸枠の抵抗を考慮した場合の地下水の非定常運動についての研究』, 第20回土木学 会年次学術講演集, 1965

（3）野满隆治：『An Advance in The Theory of Wells, 1 Steady States』日本天文学会及び地 球物理学集報12,1935, P 159 171 
（4） O. C. ッィエンキーヴィッツ著, 吉識雅夫, 山田嘉昭監訳：『基礎工学におけるマトリックス有 限要素法』，培風館，1975，P259～321

（5）星田義治, 濱野啓造, 市川勉, 前原弘光：『井戸枠の抵抗を考虑した非定常地下水流の一考察』 東海大学紀要, No. 2, 1977

（6）星田義治，濱野啓造，市川勉，前原弘光：『揚水における井戸枠の抵抗の評価に関する一考察』 土木学会論文報告集，第275号，1978，P 131～134

（受付：1979年 4月23日, 受理：1979年 5 月18日） 